\title{
Optimasi Algoritma Klasifikasi Biner dengan Tuning Parameter pada Penyakit Diabetes Mellitus
}

\author{
Wijanarto', Rhatna Puspitasari² \\ Teknik Informatika \\ Universitas Dian Nuswantoro \\ Semarang, Indonesia \\ e-mail: ${ }^{1}$ wijanarto@dsn.dinus.ac.id, ${ }^{2}$ rhatnapuspitsari97@gmail.com \\ Diajukan: 18 Juni 2019; Direvisi: 14 Agustus 2019; Diterima: 15 Agustus 2019
}

\begin{abstract}
Abstrak
Diabetes Melitus atau yang biasanya disebut dengan penyakit kencing manis merupakan penyakit yang terjadi akibat peningkatan kadar glukosa di dalam darah terlalu tinggi. Data World Health Organization (WHO), menunjukkan Indonesia menjadi negara keempat di dunia dengan angka penderita diabetes terbanyak dan mengalami peningkatan hingga 14 juta orang. Peningkatan kasus penyakit Diabetes melitus ini memerlukan suatu upaya penanggulangan dan pencegahan dini terhadap penyakit Diabetes melitus. Dalam penelitian ini akan dilakukan optimasi algoritma klasifikasi biner pada penyakit diabetes melitus mulai dari observasi, visualisasi, statistic deskriptif dataset, pre-processing dataset, penentuan baseline model, tuning parameter model dan finalisasi model. Penentuan baseline model diperoleh dengan mencari nilai akurasi tertinggi dari 3 algoritma linear (Logistic Regression, Linear Discriminant Analysis, K-nearest neighbor) atau 3 algoritma non-linear (Decision Tree, Nä̈ve Bayes, Support Vector Machine) berdasarkan tuning parameternya dan yang menghasilkan akurasi optimal adalah Algoritma Support Vector Machine, sehingga dijadikan sebagai final model dengan parameter $C$ sebesar 47 dengan kernel rbf dihasilkan rerata akurasi sebesar $77.3 \%$ pada data training dan $74.5 \%$ pada data testing, sementara berdasarkan confusion matrix dihasilkan precision 78\%, recall 83\%, f1-Score $81 \%$, error rate $25 \%$.
\end{abstract}

Kata kunci: Optimasi, Klasifikasi Biner, Tuning Parameter, Support Vector Machine.

\begin{abstract}
Diabetes mellitus or commonly referred to as diabetes is a disease that occurs due to an increase in blood glucose levels too high. Data from the World Health Organization (WHO) shows that Indonesia is the fourth country in the world with the highest number of diabetics and has increased to 14 million people. This increase in cases of diabetes mellitus requires an early prevention and prevention of diabetes mellitus. In this study, optimization of binary classification algorithms in Diabetes Mellitus will be carried out starting from observation, visualization, dataset descriptive statistics, pre-processing datasets, determining baseline models, tuning model parameters and finalizing models. Determination of the baseline model is obtained by finding the highest accuracy value of 3 linear algorithms (Logistic Regression, Linear Discriminant Analysis, K-nearest neighbor) or 3 non-linear algorithms (Decision Tree, Nä̈ve Bayes, Support Vector Machine) based on tuning parameters and resulting accuracy optimal is the Support Vector Machine Algorithm, so it is used as a final model with parameter Cof 47 with the rbf kernel resulting in an average accuracy of $77.3 \%$ in training data and $74.5 \%$ in testing data, while based on confusion matrix precision is $78 \%$, recall $83 \%$, f1 -Score $81 \%, 25 \%$ error rate.
\end{abstract}

Keywords: Optimization, Binary Classification, Tuning Parameters, Support Vector Machine.

\section{Pendahuluan}

Diabetes Melitus atau yang biasanya disebut dengan penyakit kencing manis merupakan penyakit yang terjadi akibat peningkatan kadar glukosa di dalam darah terlalu tinggi. Kadar gula di dalam darah dapat meningkat salah satunya disebabkan karena tubuh tidak dapat melepaskan atau menggunakan insulin secara normal. Setiap individu memiliki kadar glukosa yang bervariasi, kadar glukosa ini akan meningkat setelah makan kemudian akan kembali normal dalam waktu dua jam [1]. Menurut World Health Organization (WHO), Indonesia menjadi negara keempat di dunia yang memiliki angka penderita diabetes 
terbanyak dan mengalami peningkatan hingga 14 juta orang. Di mana jumlah penderita diabetes di Indonesia pada tahun 2000 adalah 8,4 juta orang setelah India (31,7 juta), Cina (20,8 juta) dan Amerika Serikat (17,7 juta). Untuk penderita diabetes di seluruh dunia, WHO melaporkan terdapat lebih dari 143 juta orang penderita, dan jumlah ini diproyeksikan prevalensinya akan meningkat menjadi dua kali lipat pada tahun 2030 dan sebanyak $77 \%$ di antaranya terjadi di negara berkembang. Selain di tingkat dunia, prevalensi diabetes melitus di Indonesia juga akan meningkat. Salah satu daerah di Indonesia yang memiliki banyaknya penderita diabetes melitus adalah Kabupaten Grobogan di mana data sampel diambil untuk penelitian ini. Diabetes melitus menjadi satu dari lima penyakit tidak menular yang paling banyak diderita di Kabupaten Grobogan. Kelima penyakit tersebut antara lain penyakit hipertensi dengan jumlah kasus yaitu (15.587 kasus), asma (6.344 kasus), diabetes melitus (4.297 kasus), gagal jantung (944 kasus) dan penyakit paru obstruksi kronik (459 kasus) [2].

Melihat kondisi tersebut maka pencegahan dan penanganan secara dini terhadap penyakit diabetes melitus menjadi sangat penting untuk dilakukan dalam rangka membantu mengklasifikasikan jumlah penderita penyakit diabetes melitus. Penelitian terkait untuk klasifikasi terhadap diabetes melitus telah dilakukan dengan menggunakan model Naïve Bayes [3] menghasilkan akurasi sebesar $80 \%$. Demikian juga dalam [1], yang mencoba membandingkan teknik C 4.5 dengan Naïve Bayes yang menghasilkan akurasi sebesar 73.30\%, nilai AUC sebesar 0.733 pada algoritma C4.5, sedangkan Naïve Bayes menghasilkan akurasi sebesar $75.13 \%$ dan nilai AUC adalah 0.810. Walaupun kelebihan metode Naïve Bayes sangat sederhana, efisien dan hanya memerlukan komputasi matematika yang tidak terlalu kompleks [4], namun kelemahan teknik ini yaitu memerlukan pengetahuan awal untuk mengambil suatu keputusan, tingkat keberhasilan metode ini sangat tergantung pada pengetahuan awal yang diberikan [5]. Sedangkan C4.5 dapat mengolah data secara berkesinambungan dengan proses yang lebih cepat dan menghasilkan pohon keputusan yang menggambarkan aturan agar lebih mudah untuk dipahami dan diimplementasikan, sedangkan kelemahan yang dimiliki adalah apabila kelas dan kriteria yang digunakan terlalu banyak maka akan terjadi tumpang tindih yang mengakibatkan bertambahnya waktu dalam pengambilan keputusan dan jumlah memori yang diperlukan [6]. Dalam penelitian lainnya [7], dengan menggunakan metode K-Nearest Neighbor didapatkan hasil yang bagus dan tangguh terhadap training data yang noisy dan efektif apabila data latihnya besar, tetapi terdapat kelemahan dalam menentukan parameter $\mathrm{K}$ (jumlah dari tetangga terdekat) yang terbaik atribut mana yang harus digunakan untuk mendapatkan hasil yang terbaik. Sementara dalam [8], melakukan uji terhadap beberapa algoritma prediksi, Logistic Regression (LR), Linear Discriminant Analysis (LDA), Quadratic Discriminant Analysis (QDA), dan K-Nearest Neighbor (KNN), semua algoritma menghasilkan standar deviasi (AUC) di bawah 0.01 dengan 10-fold cross validation, tetapi yang menghasilkan performa terbaiknya adalah LR dengan AUC 78\%. Penelitian yang dilakukan oleh [9] meng-ensemble teknik multi layer perceptron dan Bayesian Net Classification untuk data diabetes mellitus menghasilkan akurasi 81.89\%, dengan 6 fitur dan 786 dataset. Teknik ensemble lainnya (AdaBoost, Gradient Boosted Trees, dan Random Forest) dalam [10], menghasilkan akurasi 73.88\% yang diaplikasikan pada dataset Pima Indian. Dalam [11], Empat model klasifikasi yang terkenal yaitu, Decision Tree, Jaringan Syaraf Tiruan, Regresi Logistik, dan Naïve Bayes kemudian dengan teknik Bagging dan Boosting dilakukan untuk mendapatkan hasil model yang paling kuat, lalu dilakukan perbandingan dengan Random Forest yang merupakan kombinasi dari Bagging dan Decision Tree dan hasilnya optimalnya adalah Random Forest dengan akurasi sebesar 85.558\%. Penelitian lainnya [12], menyajikan studi dan analisis dari empat algoritma klasifikasi yaitu J48, Random Tree, Decision Tree dan Naïve Bayes untuk Diabetic dataset dan kinerjanya dibandingkan dengan menggunakan ukuran seperti waktu komputasi, contoh yang diklasifikasikan dengan benar dan salah, statistik kappa, Presisi, Recall dan F-Score. Hasil percobaan menunjukkan bahwa J48 memberikan akurasi yang lebih baik daripada decision tree dan Naïve Bayes. Boosting model juga dilakukan dalam [13], pengujian statistik non-parametrik dilakukan pada ratusan hasil indeks pengukuran medis antara populasi diabetes dan non-diabetes. Dua algoritma peningkatan yang umum, Adaboost.M1 dan LogitBoost, dipilih untuk membuat model mesin untuk diagnosis diabetes berdasarkan data uji klinis ini, yang melibatkan total 35.669 individu. Model klasifikasi mesin yang dibangun oleh kedua algoritma ini memiliki klasifikasi yang sangat baik kemampuannya. Di sini, model klasifikasi LogitBoost sedikit lebih baik daripada model klasifikasi Adaboost.M1. Keakuratan keseluruhan dari model klasifikasi LogitBoost mencapai 95,30\% ketika menggunakan validasi silang $10 \mathrm{kali}$ lipat. Nilai true positive, true negative, false positive, dan false negative dari model klasifikasi biner masing-masing adalah 0,921,0,969,0,031, dan 0,079, dan area di bawah kurva karakteristik operasi penerima mencapai 0,99 .

Berdasarkan beberapa penelitian terdahulu yang terkait, penelitian ini mencoba mencari metode optimal pada data kecil untuk mengklasifikasikan penyakit diabetes mellitus berdasarkan 3 algoritma linear dan 3 algoritma non-linear yang dijadikan sebagai baseline model untuk dilakukan tuning parameter

Optimasi Algoritma Klasifikasi Biner dengan Tuning Parameter pada Penyakit Diabetus Mellitus (Wijanarto) 
terhadapnya sehingga menghasilkan model yang optimal yang dapat menentukan klasifikasi penyakit diabetes atau non-diabetes.

\section{Metode Penelitian}

Dalam menentukan algoritma atau model machine learning yang terbaik sangatlah sulit terutama pada supervised learning, karena sangat terbuka kemungkinan model yang terbaik tergantung pada parameter yang diberikannya. Dalam penelitian ini akan menggunakan kerangka atau framework penelitian seperti pada Gambar 1 di bawah ini.

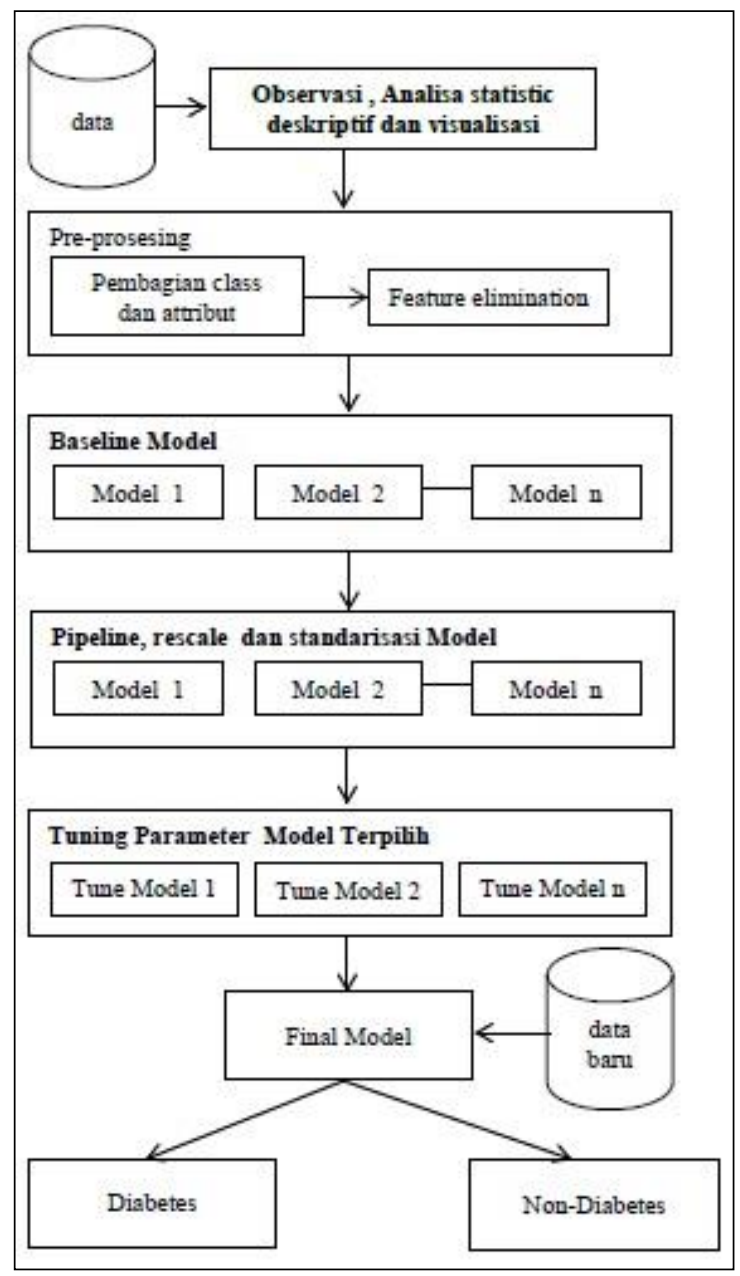

Gambar 1. Kerangka kerja penelitian.

\subsection{Dataset}

Dataset yang digunakan adalah dataset penyakit diabetes melitus dari RSUD. Dr. R Soedjati Purwodadi, yang terdiri dari 271 data record, yang terdiri dari 160 data diklasifikasikan sebagai penderita diabetes dan 111 data sebagai non-diabetes, juga terdapat 8 atribut, 7 atribut dengan 1 class, seperti Tabe 1 1 di bawah ini.

Tabel 1. Feature dataset.

\begin{tabular}{|c|c|}
\hline ID Feature & Nama Feature \\
\hline $\mathrm{X} 1$ & Usia \\
\hline $\mathrm{X} 2$ & Gender \\
\hline $\mathrm{X} 3$ & Gula Darah Sesaat \\
\hline $\mathrm{X} 4$ & Tekanan Darah \\
\hline $\mathrm{X} 5$ & Riwayat DM \\
\hline $\mathrm{X} 6$ & Alkoholic \\
\hline $\mathrm{X} 7$ & Perokok \\
\hline TARGET & Diabetes (1) atau Non Diabetes $(0)$ \\
\hline
\end{tabular}




\subsection{Observasi, Statistic Deskriptif, dan Visualisasi}

Kerangka kerja penelitian ini pertama-tama akan dilakukan observasi dengan statistic deskriptif, untuk mendapatkan gambaran mengenai data yang akan dilakukan pemrosesan awal (jumlah, tipe, unit, skala) dan statistic deskriptif (jumlah atribut, nilai maximum, minimum, rerata, deviasi, Q1,Q2,Q3) dengan pustaka pandas. Visualisasi data akan dilakukan dengan matplotlib dan seaborn yang terdiri dari analisis univariate untuk melihat histogram, density, distribusi cumulative, analisis bivariate dengan box dan whisker untuk melihat sebaran Q1,Q2,Q3,Q4 dan outlier dataset, analisis multivariate dengan scatter plot matrix untuk melihat sebaran data dan terakhir analisis korelasi matrix pada atribut untuk melihat korelasi antar atribut sebelum dilakukan feature eliminasi dan meyakinkan apakah data perlu dilakukan pemrosesan awal yang lebih baik.

\subsection{Pre-prosesing: Pembagian Data dan Eliminasi Fitur}

Setelah didapatkan observasi awal maka langkah selanjutnya adalah melakukan pemrosesan data awal yaitu melakukan pembagian data (class dan atribut), k-fold validation (cross validation dipilih 10fold validation) dan feature elimination dengan pustaka sklearn dengan mengaplikasikan metode chisquare, feature classification, mutual information classification. Ketiga metode tadi diaplikasikan pada fungsi SelectKBest untuk mendapatkan $k$ feature terpilih dari pustaka sklearn, dalam klasifikasi biner akurasi akan lebih meningkat jika atribut lebih sederhana dan nilai data lebih homogen.

\subsection{Baseline Model: Best Feature Selection}

Langkah selanjutnya adalah menentukan baseline model atau algoritma dari 3 algoritma linier (Logistic Regression, Linear Discriminant Analysis, K-Nearest Neighbors) dan 3 algoritma non-linear (Decision Tree, Gaussian Naïve Bayes, Support Vector Machine) berdasarkan metode feature eliminiation yang terbaik (chi-square, feature classification, atau mutual information classification). Berdasarkan baseline ini maka dapat ditentukan model terbaik untuk feature terpilih dengan akurasi tertinggi.

\subsection{Pipelining: Rescale dan Standardization}

Setelah didapatkan baseline model yang dicurigai menghasilkan nilai terbaik, maka langkah selanjutnya adalah melakukan penyekalaan ulang dan standardisasi data dan membandingkannya dengan baseline model dengan feature terpilih, sehingga dari hasil perbandingan tersebut didapatkan model terbaik dari dataset yang sudah distandardisasi dengan fitur terpilih, yang mungkin lebih dari satu model yang dicurigai menghasilkan akurasi yang bagus. Langkah ini mengaplikasikan fungsi Pipeline dari pustaka sklearn dengan perhitungan StandardScaler seperti persamaan 1 berikut di bawah:

$$
\bar{X}=\frac{X_{i}-\operatorname{mean}(x)}{S D(x)}
$$

$\mathrm{X}_{\mathrm{i}} \quad=$ nilai variabel input data mentah $\mathrm{X}$ untuk kasus pelatihan ke- $i$

$\operatorname{Mean}(\mathrm{X})=$ rata-rata vektor fitur tersebut

$\mathrm{SD}(\mathrm{X}) \quad=$ nilai standar yang berhubungan dengan $\mathrm{X}_{\mathrm{i}}$

Dua cara paling berguna untuk menstandardisasi input adalah mean 0 dan standar deviasi 1 , serta midrange 0 dan range 2 (mis., minimum -1 dan maksimum 1). Perhatikan bahwa statistik seperti mean dan standar deviasi dihitung dari data pelatihan, bukan dari validasi atau data uji. Validasi dan data uji harus distandardisasi menggunakan statistik yang dihitung dari data pelatihan.

\subsection{Tuning Parameter}

Tuning parameter dilakukan pada beberapa model yang dihasilkan setelah dilakukan pipelining. Tuning parameter sesuai dengan model yang terpilih dengan memberi nilai yang optimal (ditunjukkan dengan grafik siku/elbow graphic, titik perubahan (garis merah) merupakan nilai optimal dari list parameter yang diberikan pada Gambar 2) sesuai parameter algoritma, nilai selanjutnya cenderung sama atau bahkan menurun. 


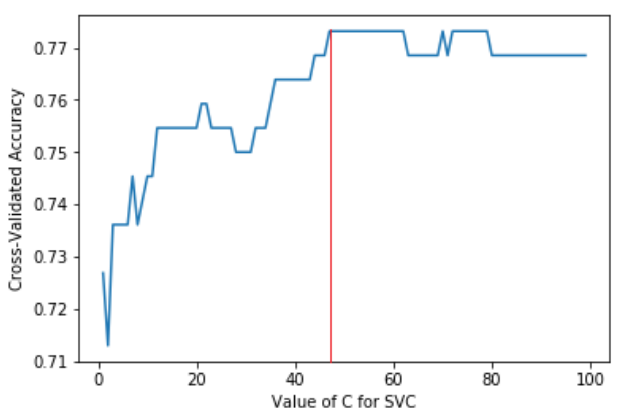

Gambar 2. Elbow Graph.

\subsection{Finalisasi Model}

Hasil akhir setelah tuning parameter adalah model terpilih yang terakhir (Final Model), model ini adalah yang dihasilkan yang terbaik berdasarkan parameter yang optimal (berdasarkan grafik siku). Dari final model ini akan diuji performanya dengan confusion matrix untuk mendapatkan Acuracy, Presision, Recall dan F1-Score serta diuji dengan data baru untuk menghasilkan klasifikasi biner yang diinginkan apakah diabetes atau non-diabetes, seperti Tabel 2 di bawah ini.

Tabel 2. Confussion Matrix.

\begin{tabular}{llll}
\hline Aktual vs Prediksi & Positive & Negative & Precission \\
\hline Positive & TP & FP & TP/(TP+FP) \\
\hline Negative & FN & TN & TP/(TP+FP) \\
\hline Recall & TP/(TP+FN $)$ & TP/(TP+FN $)$ & \\
\hline
\end{tabular}

Kinerja model dapat dievaluasi berbagai kinerja langkah-langkah: akurasi klasifikasi, sensitivitas, dan spesifisitas. Langkah-langkah ini dievaluasi menggunakan true positive (TP), true negatif (TN), false positive (FP), dan false negative $(\mathrm{FN})$. Nilai Akurasi didapatkan dengan $(\mathrm{TP}+\mathrm{TN}) /(\mathrm{TP}+\mathrm{TN}+\mathrm{FP}+\mathrm{FN})$, sementara F1-Score adalah 2.TP/2.TP+FP+FN. Aplikasi dari kerangka kerja penelitian diatas menggunakan pustaka machine learning (numpy, pandas, matplotlib, seaborn, pickle, sklearn) dari bahasa Python 3.7.

\section{Hasil dan Pembahasan}

Berdasarkan kerangka kerja penelitian yang diusulkan pada bagian sebelumnya, maka didapatkan hasil sebagai berikut di bawah ini.

\subsection{Observasi dan Visualisasi Data Statistik Deskriptif}

Data diperoleh dari penelitian sebelumnya [15], dengan ukuran sebesar (271 baris, 8 feature) selengkapnya terlihat pada Tabel 3 berikut ini:

Tabel 3. Statistik deskriptif.

\begin{tabular}{|c|c|c|c|c|c|c|c|c|}
\hline & UMUR & GENDER & GDS & TD & DM & ALC & CGR & TARGET \\
\hline count & 271.00 & 271.00 & 271.00 & 271.00 & 271.00 & 271.00 & 271.00 & 271.00 \\
\hline mean & 53.49 & 0.47 & 300.90 & 130.70 & 0.59 & 0.20 & 0.15 & 0.59 \\
\hline std & 8.00 & 0.50 & 101.19 & 31.13 & 0.49 & 0.40 & 0.36 & 0.49 \\
\hline $\min$ & 35.00 & 0.00 & 104.00 & 90.00 & 0.00 & 0.00 & 0.00 & 0.00 \\
\hline $25 \%$ & 48.00 & 0.00 & 197.00 & 110.00 & 0.00 & 0.00 & 0.00 & 0.00 \\
\hline $50 \%$ & 55.00 & 0.00 & 327.00 & 128.00 & 1.00 & 0.00 & 0.00 & 1.00 \\
\hline $75 \%$ & 60.00 & 1.00 & 390.00 & 142.00 & 1.00 & 0.00 & 0.00 & 1.00 \\
\hline $\max$ & 70.00 & 1.00 & 450.00 & 405.00 & 1.00 & 1.00 & 1.00 & 1.00 \\
\hline \multicolumn{9}{|c|}{ TARGET } \\
\hline $\mathbf{0}$ & 111 & & & & & & & \\
\hline 1 & 160 & & & & & & & \\
\hline
\end{tabular}

Berdasarkan Tabel 3 di atas maka dapat disimpulkan sementara bahwa data memiliki 271 baris dengan 8 kolom/fitur, semuanya memiliki tipe integer, terdapat fitur dengan skala berbeda usia termuda adalah 35 tahun dan tertua adalah 70 tahun, rerata usianya 53 dengan standar deviasi sebesar 8 (7.99), 
Nilai Gula darah sesaat (GDS) terendah sebesar 104 dan tertinggi sebesar 450, dengan rerata sebesar 300, dan standar deviasinya sebesar 101, sementara Tekanan Darah (TD) terendah sebesar 90, tertinggi sebesar 405, reratanya 130 dengan standar deviasi sebesar 3, dari 271 data, TARGET: 111=NON-DM, dan 160=DM, berikut visualisasi yang dihasilkan pada Gambar 3 berikut:

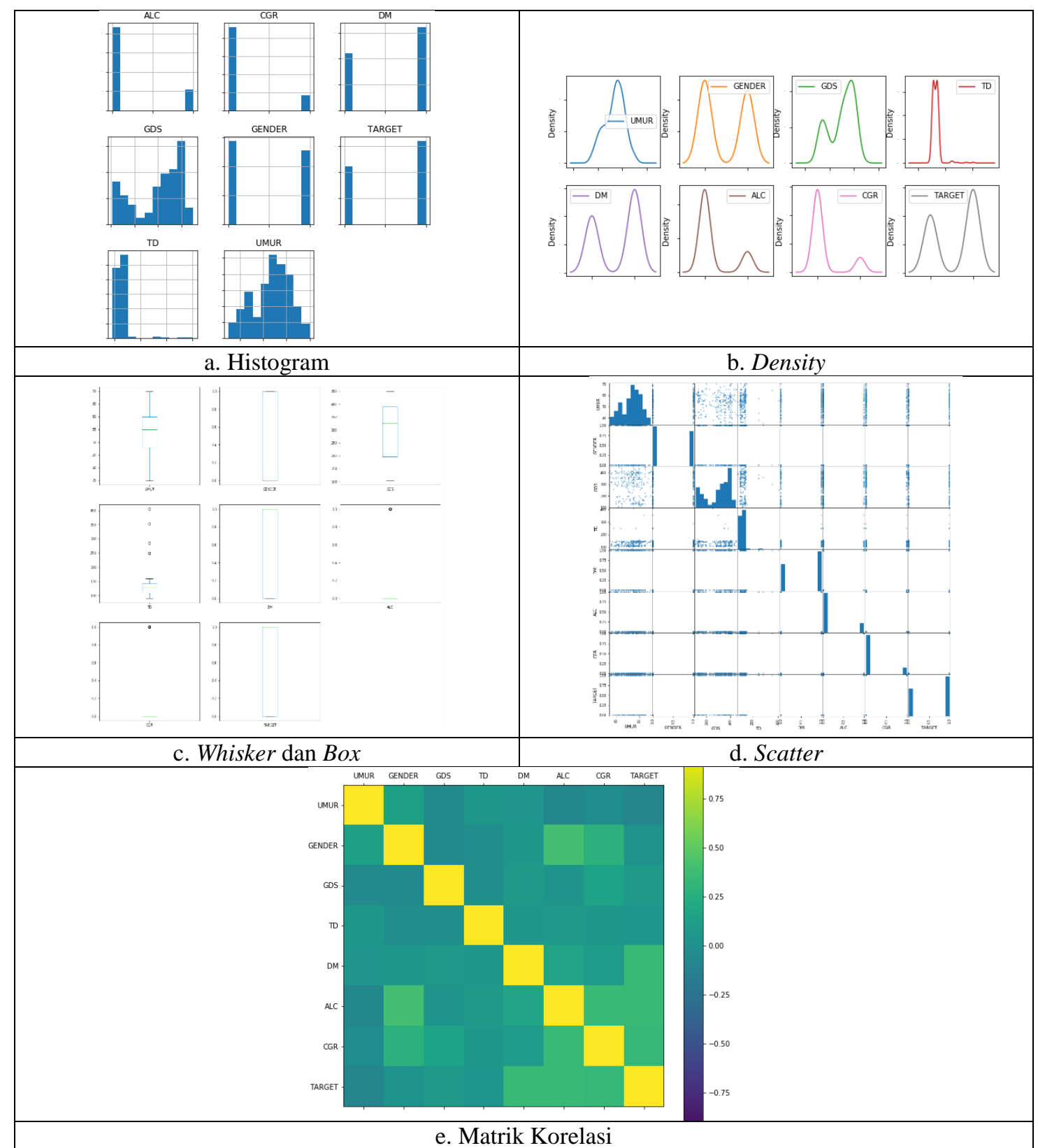

Gambar 3. Visualisasi Dataset.

Gambar 3.a memperkuat dugaan bahwa dataset tidak normal (hanya terdapat 2 fitur yang cenderung normal GDS dan UMUR), hal ini diperkuat dengan Gambar 3.b, c, dan d arah skewness terlihat jelas pada GDS dan UMUR. Sementara hasil korelasi matrik menunjukkan hampir tidak terdapat korelasi baik secara positif maupun negative antara 2 fitur yang berhubungan.

\subsection{Pre-Processing}

Pada bagian ini dilakukan pembagian class dan atribut pada dataset serta feature elimination. Data dibagi menjadi 1 class (TARGET) dan 7 atribut (UMUR, GENDER, GDS, TD, DM, ALC, CGR) di mana GDS (Nilai Gula Dara Sesaat), DM (Kategori Diabetes Mellitus Keturunan atau tidak), TD (Nilai Tekanan Darah), ALC (Kategori Alcoholic atau tidak), CGR (Kategori Perokok atau tidak) dengan perbandingan

Optimasi Algoritma Klasifikasi Biner dengan Tuning Parameter pada Penyakit Diabetus Mellitus (Wijanarto) 
sebesar 20:80. Feature elimination dilakukan dengan 3 teknik dengan mencari nilai akurasi yang tertinggi yaitu Chi-Square, ANOVA F-Value dan Mutual Information Untuk Target Kontinyu terhadap 5 feature terbaik, dan didapatkan hasil pada Tabel 4 sebagai berikut:

Tabel 4. Skor Atribut Feature Elimination.

\begin{tabular}{|c|c|c|c|c|c|c|c|c|}
\hline \multirow{2}{*}{ Metode } & \multicolumn{7}{|c|}{ Skor } & \multirow{2}{*}{5 Atribut terpilih } \\
\hline & UMUR & GENDER & GDS & TD & DM & ALC & CGR & \\
\hline Chi-Square & 2.495 & 0.133 & 46.73 & 5.775 & 13.522 & 27.989 & 25.157 & $\begin{array}{l}\text { GDS, TD, DM, ALC, } \\
\text { CGR }\end{array}$ \\
\hline $\begin{array}{l}\text { ANOVA } \\
\text { F-Value }\end{array}$ & 2.097 & 0.248 & 1.375 & 0.778 & 37.701 & 39.834 & 33.036 & $\begin{array}{l}\text { UMUR, GDS, DM, } \\
\text { ALC, CGR }\end{array}$ \\
\hline $\begin{array}{l}\text { Mutual } \\
\text { information }\end{array}$ & 0.036 & 0 . & 0.062 & 0.083 & 0.092 & 0.113 & 0.077 & $\begin{array}{l}\text { GDS, TD, DM, } \\
\text { ALC, CGR }\end{array}$ \\
\hline
\end{tabular}

\subsection{Baseline Model}

Setelah mendapatkan 5 urutan feature terbaik yang dipilih, maka kita akan menentukan baseline model berdasarkan fitur terbaik yang didapatkan dengan 3 teknik di atas menggunakan 3 algoritma klasifikasi linear dan 3 algoritma klasifikasi non-linear. Enam algoritma di atas dipilih berdasarkan intuisi dan seringnya algoritma klasifikasi di atas dipakai dalam machine learning, sehingga didapatkan hasil seperti Tabel 5 sebagai berikut:

Tabel 5. Baseline model terpilih.

\begin{tabular}{|c|c|c|c|c|c|c|}
\hline \multirow[b]{2}{*}{ Model } & \multicolumn{2}{|c|}{ Chi-square } & \multicolumn{2}{|c|}{ ANOVA F-Value } & \multicolumn{2}{|c|}{$\begin{array}{c}\text { Mutual } \\
\text { Information }\end{array}$} \\
\hline & Mean & STD & Mean & STD & Mean & STD \\
\hline Logistic Regression & 0.713636 & 0.089423 & 0.718182 & 0.091140 & 0.713636 & 0.089423 \\
\hline $\begin{array}{l}\text { Linear Discriminant } \\
\text { Analysis }\end{array}$ & 0.713636 & 0.089423 & 0.718182 & 0.091140 & 0.713636 & 0.089423 \\
\hline K-Nearest Neighbors & 0.611905 & 0.076023 & 0.481818 & 0.120457 & 0.491991 & 0.094849 \\
\hline Decision Tree & 0.685281 & 0.057432 & 0.648485 & 0.072245 & 0.634199 & 0.092097 \\
\hline Gaussian Naïve Bayes & 0.638961 & 0.125690 & 0.638961 & 0.125690 & 0.638961 & 0.125690 \\
\hline Support Vector Machine & 0.639177 & 0.085008 & 0.596753 & 0.129274 & 0.509957 & 0.096378 \\
\hline
\end{tabular}

Terlihat 2 model (Logistic Regression dan Linear Discriminant Analysis) dengan ANOVA FValue menghasilkan akurasi tertinggi $71.8182 \%$ maka Feature Elimination yang dipakai adalah adalah yang menggunakan teknik ANOVA F-Value (UMUR, GDS, DM, ALC, CGR) sehingga sementara baseline algoritma yang akan dilakukan studi adalah Logistic Regression dan Linear Discriminant Analysis.

\subsection{Pipelining, Rescale, dan Standardisasi Data}

Walaupun baseline model telah tampak, namun masih berdasarkan feature terpilih, sementara dataset belum dilakukan rescaling dengan standardisasi. Pada Tabel 6 berikut akan dilakukan rescale dan menentukan model yang akan dilakukan tuning parameter dan berikut hasil yang didapatkan setelah feature selection dan standardisasi dengan fungsi StandardScaler:

Tabel 6. Akurasi Model Pipelining dan Standardisasi.

\begin{tabular}{|c|c|c|c|c|c|c|}
\hline \multirow[b]{2}{*}{ Model } & \multicolumn{2}{|c|}{ Chi-square } & \multicolumn{2}{|c|}{ ANOVA F-Value } & \multicolumn{2}{|c|}{$\begin{array}{c}\text { Mutual } \\
\text { Information }\end{array}$} \\
\hline & Mean & STD & Mean & STD & Mean & STD \\
\hline Logistic Regression & 0.713636 & 0.089423 & 0.718182 & 0.091140 & 0.718182 & 0.091140 \\
\hline $\begin{array}{l}\text { Linear Discriminant } \\
\text { Analysis }\end{array}$ & 0.713636 & 0.089423 & 0.718182 & 0.091140 & 0.713636 & 0.089423 \\
\hline K-Nearest Neighbors & 0.680736 & 0.076381 & 0.713853 & 0.099623 & 0.710173 & 0.121677 \\
\hline Decision Tree & 0.680736 & 0.072174 & 0.671861 & 0.066427 & 0.661472 & 0.099610 \\
\hline Naïve Bayes & 0.638961 & 0.125690 & 0.638961 & 0.125690 & 0.638961 & 0.125690 \\
\hline Support Vector Machine & 0.713636 & 0.089423 & 0.713203 & 0.097322 & 0.727489 & 0.088042 \\
\hline
\end{tabular}

Berdasarkan hasil standardisasi dengan pipelining berdasarkan 5 feature terpilih, didapatkan hasil yang mengejutkan, KNN dan SVM mengambil alih performa, K-Nearest Neighbors (KNN) dengan metode feature elimination ANOVA F-Value sebesar 71.3853 dan Support Vector Machine (SVM) dengan metode mutual information classification sebesar 72.7489, seperti pada Tabel 6 di atas. Dengan demikian baseline algoritma bergeser ke KNN dan SVM untuk dilakukan tuning. 


\subsection{Tuning Parameter Model}

Tuning parameter akan dilakukan terhadap 2 algoritma terpilih yang memiliki akurasi tertinggi setalah dilakukan pipelining yaitu KNN dan SVM. Parameter pada model KNN hanya didasarkan pada nilai $\mathrm{k}$ yang akan diberi parameter 1 hingga 31 dengan bobot uniform, sementara cross validation ditetapkan dengan 10-fold validation, aplikasi tuning dilakukan dengan fungsi GridSearch dari sklearn sehingga kita dapat dengan mudah mendapatkan skor dan parameter terbaik, seperti ditampilkan pada Tabel 7 berikut ini.

Tabel 7. Tuning n neighbors pada model KNN.

\begin{tabular}{|c|c|c|c|}
\hline Mean Score & SD Score & Neighbors & Bobot \\
\hline 0.708333 & 0.115261 & 1 & \multirow{30}{*}{ uniform } \\
\hline 0.685185 & 0.127127 & 2 & \\
\hline 0.689815 & 0.124167 & 3 & \\
\hline 0.726852 & 0.141446 & 4 & \\
\hline 0.708333 & 0.103100 & 5 & \\
\hline 0.708333 & 0.085865 & 6 & \\
\hline 0.708333 & 0.093411 & 7 & \\
\hline 0.699074 & 0.090548 & 8 & \\
\hline 0.699074 & 0.092030 & 9 & \\
\hline 0.675926 & 0.098002 & 10 & \\
\hline 0.685185 & 0.087256 & 11 & \\
\hline 0.694444 & 0.104942 & 12 & \\
\hline 0.703704 & 0.108746 & 13 & \\
\hline 0.712963 & 0.107402 & 14 & \\
\hline 0.717593 & 0.099310 & 15 & \\
\hline 0.708333 & 0.088960 & 16 & \\
\hline 0.708333 & 0.094265 & 17 & \\
\hline 0.703704 & 0.093484 & 18 & \\
\hline 0.740741 & 0.102402 & 19 & \\
\hline 0.740741 & 0.100675 & 20 & \\
\hline 0.736111 & 0.095270 & 21 & \\
\hline 0.722222 & 0.088126 & 22 & \\
\hline 0.731481 & 0.088906 & 23 & \\
\hline 0.726852 & 0.087814 & 24 & \\
\hline 0.722222 & 0.094756 & 25 & \\
\hline 0.722222 & 0.092020 & 26 & \\
\hline 0.712963 & 0.089093 & 27 & \\
\hline 0.712963 & 0.083580 & 28 & \\
\hline 0.708333 & 0.085338 & 29 & \\
\hline 0.708333 & 0.078743 & 30 & \\
\hline
\end{tabular}

Dari Tabel 7 di atas maka kita dapat melihat pada posisi $n=19$, didapatkan akurasi sebesar $\mathbf{7 4 \%}$, jika kita plot dalam bentuk graphic elbow pada Gambar 4 kita dapat melihat performa terbaiknya dengan visualisasi yang lebih jelas pada garis vertical merah sebagai berikut:

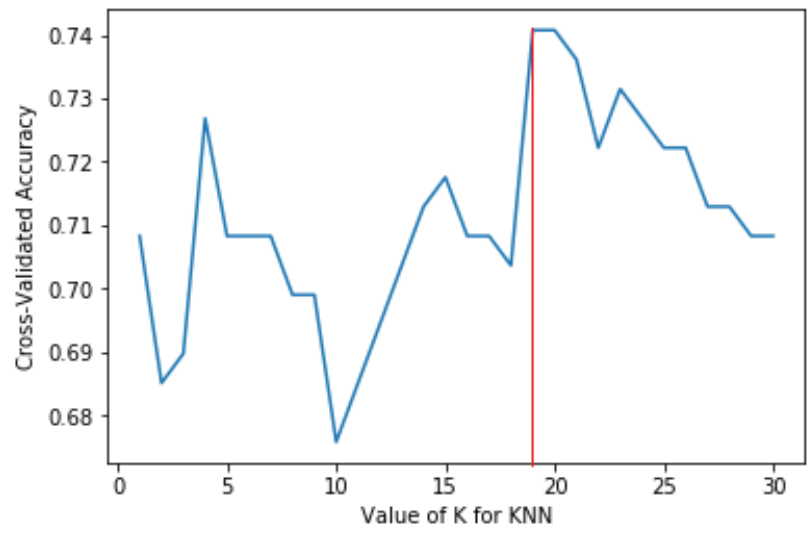

Gambar 4. Grafic Elbow Tuning Paramater Model KNN. 
Sementara itu tuning pada model SVM, parameter yang diperlukan adalah nilai C, gamma, kernel yang akan dikombinasikan. Parameter $\mathrm{C}$ akan diberi nilai mulai dari 1 hingga 100, Parameter gamma antara 0.001 hingga 0.0001 , sementara kernel yang dipilih adalah linear, polynomial, sigmoid. Ketiga parameter ini akan dikombinasikan dan untuk menghemat tempat yang ditampilkan adalah kombinasi yang menghasilkan nilai optimal, seperti pada Tabel 8 di bawah ini.

Tabel 8. Tuning Nilai C dan kernel pada model SVM.

\begin{tabular}{|c|c|c|c|}
\hline Mean Score & SD Score & $\mathrm{C}$ & Kernel \\
\hline 0.726852 & 0.115261 & 1 & \\
\hline 0.712963 & 0.127127 & 2 & \\
\hline 0.736111 & 0.124167 & 3 & \\
\hline 0.736111 & 0.141446 & 4 & \\
\hline 0.736111 & 0.103100 & 5 & \\
\hline$\ldots$ & $\ldots$ & $\ldots$ & \\
\hline 0.754630 & 0.108180 & 20 & \\
\hline$\ldots$ & $\ldots$ & $\ldots$ & \\
\hline 0.763889 & 0.106730 & 40 & \\
\hline 0.763889 & 0.106730 & 41 & \\
\hline 0.763889 & 0.106730 & 42 & \\
\hline 0.763889 & 0.106730 & 43 & \\
\hline 0.768519 & 0.106024 & 44 & \\
\hline 0.768519 & 0.106024 & 45 & \\
\hline 0.768519 & 0.106024 & 46 & $r b f$ \\
\hline 0.773148 & 0.107094 & 47 & \\
\hline 0.773148 & 0.107094 & 48 & \\
\hline 0.773148 & 0.107094 & 49 & \\
\hline 0.773148 & 0.107094 & 50 & \\
\hline$\ldots$ & $\ldots$ & $\ldots$ & \\
\hline 0.773148 & 0.107094 & 60 & \\
\hline$\ldots$ & $\ldots$ & $\ldots$ & \\
\hline 0.773148 & 0.103089 & 70 & \\
\hline$\ldots$ & $\ldots$ & $\ldots$ & \\
\hline 0.768519 & 0.100243 & 80 & \\
\hline$\ldots$ & $\ldots$ & $\ldots$ & \\
\hline 0.768519 & 0.0 .100243 & 90 & \\
\hline$\ldots$ &. &.. & \\
\hline 0.768519 & 0.100243 & 99 & \\
\hline
\end{tabular}

Dari Tabel 8 di atas maka kita dapat melihat pada posisi $\mathbf{C =} \mathbf{4 7}$ - 62 atau 70 atau 72 - 79 dengan kombinasi kernel rbf, didapatkan akurasi sebesar 77\%, jika kita plot dalam bentuk graphic elbow pada Gambar 5 kita dapat melihat performa terbaiknya dengan visualisasi yang lebih jelas pada garis vertical merah sebagai berikut:

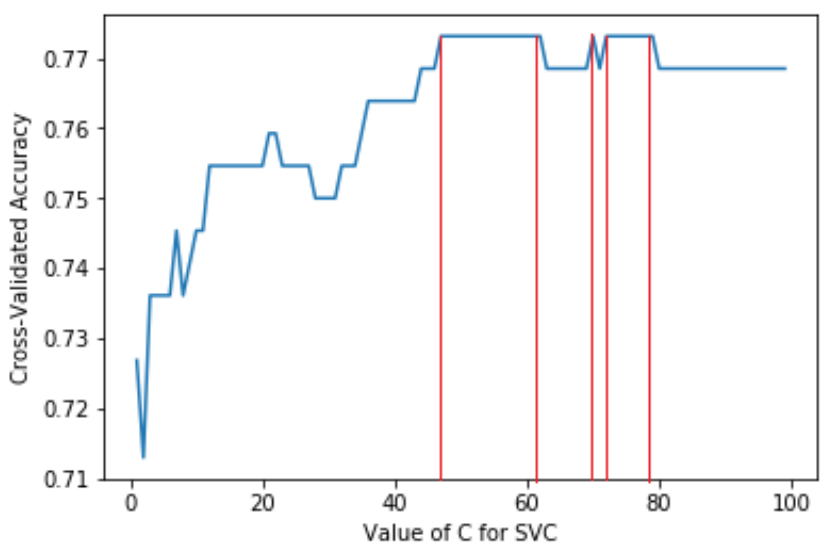

Gambar 5. Grafic Elbow Tuning Paramater Model SVM.

\subsection{Finalisasi Model}

Berdasarkan hasil tuning terhadap 2 algoritma di atas dan yang mempunyai nilai akurasi tertinggi adalah model SVM, dengan demikian maka model SVM menjadi model terakhir yang akan dipakai dalam 
mengklasifikasi penyakit diabetes mellitus sesuai dengan atribut terpilih (Umur, Gender, Gula darah Sesaat, Tekanan Darah, Riwayat DM, Alcoholic, dan Perokok) yang sudah distandardisasi. Hasil performa dievaluasi dengan mengukur rerata akurasi pada data testing, confussion matrix dengan 10-fold validation, dihasilkan sebagai berikut akurasi sebesar 76\%, sementara confussion matrix untuk data testing 54 record seperti Tabel 9 di bawah.

Tabel 9. Confussion Matrix data testing Model SVM.

\begin{tabular}{ccccc}
\hline Aktual vs Prediksi & Positive & Negative & & \\
\hline Positive & 12 & 8 & & \\
\hline Negative & 6 & 29 & & \\
\hline & & & f1-score & Support \\
\hline 0 & precision & recall & 0.63 & 20 \\
\hline 1 & 0.67 & 0.60 & 0.81 & 35 \\
\hline
\end{tabular}

\section{Kesimpulan}

Berdasarkan hasil penelitian yang sudah dilakukan, maka sementara ini dapat disimpulkan model klasifikasi biner yang optimal dari 3 algoritma linear dan 3 algoritma non-linear, terhadap dataset kecil dengan atribut kecil adalah model Support Vector Machine (SVM). Model SVM ini optimal dengan parameter nilai $\mathrm{C}$ atau Center $=47-62$ atau 70 atau 72-79, sementara kernel yang diberikan adalah rbf (radial basis function, nilai riil pada fungsi gamma yang nilainya tergantung pada jarak dengan titik origin). Model SVM menghasilkan akurasi optimal 76.3\% dengan kernel rbf dan untuk nilai $\mathrm{C}$ antara 4762 atau 70 atau 72-79, didapatkan akurasi tertinggi pada nilai $C=70$ sebesar $76.3 \%$, sementara presisinya $78 \%$ dengan recall $83 \%$ dan skor F1 test sebesar $81 \%$. Ke depan perlu dilakukan kombinasi tidak saja model linear, non-linear tetapi juga dengan model berbasis neural network dan fuzzy neural network. Selain itu perlu dipikirkan juga untuk melakukan komparasi kombinasi model ensemble (boosting dan bagging) dengan tuning parameter model linear dan non-linear.

\section{Daftar Pustaka}

[1] Fatmawati, "Perbandingan Algoritma Klasifikasi Data Mining Model C4.5 Dan Naïve Bayes Untuk Prediksi Penyakit Diabetes," J. Techno Nusa Mandiri, vol. XIII, no. 1, p. 50, 2016.

[2] J. J. Pangaribuan, "Mendiagnosa Penyakit Diabetes Mellitus Dengan Menggunakan Metode Extreme Learning Machine," 2016.

[3] I. L. Qurnia, E. Prasetyo, and R. F. Zainal, "Classification Of Diabetes Disease Using Nive Bayes Case Study : Siti Khadijah Hospital,” 2016.

[4] A. W. W. Wayan Firdaus Mahmudy, "Klasifikasi Artikel Berita Secara Otomatis Menggunakan Metode Naïve Bayes Classifier Yang Dimodifikasi," TEKNO, vol. 21 Maret, 2014.

[5] S. Natalius, "Makalah II 2092 Probabilitas dan Statistik-Sem. I Tahun," 2010.

[6] F. Maspiyanti and J. Gatc, "Diagnosa Penyakit Jantung Pada Ponsel Menggunakan Pohon Keputusan," J. Teknol. Terpadu, vol. 1, no. 1, 2015.

[7] M. Lestari, "Penerapan Algoritma Klasifikasi Nearest Neighbor (K-NN) Untuk Mendeteksi Penyakit Jantung," 2014.

[8] B. G. Choi, S. W. Rha, S. W. Kim, J. H. Kang, J. Y. Park, and Y. K. Noh, "Machine learning for the prediction of new-onset diabetes mellitus during 5-year follow-up in non-diabetic patients with cardiovascular risks," Yonsei Med. J., vol. 60, no. 2, pp. 191-199, Feb. 2019.

[9] P. A. Amit kumar Dewangan, "Classification of Diabetes Mellitus Using Machine Learning Techniques,” Int. J. Eng. Appl. Sci., vol. 2, no. 5, pp. 145-148, 2015.

[10] K. Akyol and B. Şen, "Diabetes Mellitus Data Classification by Cascading of Feature Selection Methods and Ensemble Learning Algorithms," Int. J. Mod. Educ. Comput. Sci., vol. 10, no. 6, pp. 1016, Jun. 2018.

[11] N. Nai-Arun and R. Moungmai, "Comparison of Classifiers for the Risk of Diabetes Prediction," in Procedia Computer Science, 2015, vol. 69, pp. 132-142.

[12] R. P. R. S. Suryakirani, "Comparative Study and Analysis of Classification Algorithms In Data Mining Using Diabetic Dataset,” IJSRST, vol. 4, no. 2, pp. 299-304, 2018.

[13] P. Chen and C. Pan, "Diabetes classification model based on boosting algorithms," BMC Bioinformatics, vol. 19, no. 1, Mar. 2018. 